\title{
THE RELATIONSHIP BETWEEN SERUM URIC ACID CONCENTRATION AND CARDIOVASCULAR RISK FACTORS IN NORMOTENSIVE POSTMENOPAUSAL WOMEN WITH DYSLIPIDEMIA
}

\author{
Małgorzata Dobrzyńska西, Juliusz Przysławski \\ Department of Bromatology, Poznan University of Medical Sciences \\ Marcelińska 42, 60-354 Poznań, Poland
}

\begin{abstract}
Background. According to the latest recommendation for patients with hyperuricemia and high cardiovascular risk, the serum uric acid (SUA) concentration should be lower than $5 \mathrm{mg} / \mathrm{dL}(<298 \mu \mathrm{mol} / \mathrm{L})$. Additionally, studies have shown that SUA concentration in participants with hyperuricemia correlates with some dietary factors. The aim of this study was to assess the relationship between SUA concentration and some cardiovascular risk factors.

Material and methods. Fifty-six postmenopausal women with dyslipidemia and without hypertension were assigned to 2 groups based on SUA concentration. The first group consisted of women with a SUA concentration $\geq 5 \mathrm{mg} / \mathrm{dL}$ and without gout, and the second group comprised women with a SUA concentration $<5 \mathrm{mg} / \mathrm{dL}$. Anthropometric parameters, nutrition, structure of consumption, dietary potential renal acid load (PRAL), lipid profile parameters and blood pressure were evaluated.

Results. Postmenopausal women with a SUA $\geq 5 \mathrm{mg} / \mathrm{dL}$ had statistically significant higher values of serum triglyceride (TG) concentration, waist-to-hip ratio (WHR) and diastolic blood pressure than women with a SUA concentration $<5 \mathrm{mg} / \mathrm{dL}$. Analysis of nutrition showed statistically significant differences between the groups in the intake of starch, saturated and polyunsaturated fatty acids, cholesterol and vitamin E. Additionally, we observed a correlation between PRAL value and SUA. The structure of consumption between the groups was varied.
\end{abstract}

Conclusion. SUA concentration $\geq 5 \mathrm{mg} / \mathrm{dL}$ may increase the cardiovascular risk. The association observed between PRAL and SUA can be used to evaluate diet.

Keywords: uric acid, cardiovascular disease, postmenopausal, nutrition, dietary potential renal acid load

\section{INTRODUCTION}

Uric acid is the final product of purine metabolism in humans. About two-thirds of total body urate is produced endogenously in the liver, while the other part is derived from diet (Batta, 2016). In some disorders, the SUA concentration is higher than the norm. It is related to overproduction or insufficient excretion. Increased production may be due to a high level of purine in the diet and increased purine metabolism and

The study was funded from the status budget of the Department of Bromatology, Poznan University of Medical Sciences.

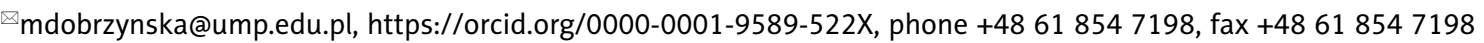


Dobrzyńska, M., Przysławski, J. (2020). The relationship between serum uric acid concentration and cardiovascular risk factors in normotensive postmenopausal women with dyslipidemia. Acta Sci. Pol. Technol. Aliment., 19(1), 123-131. http://dx.doi. org/10.17306/J.AFS.2020.0740

genetic factors (Luo et al., 2019). Causes of decreased excretion primarily include chronic kidney disease. Hyperuricemia occurs when the SUA concentration exceeds is $360 \mu \mathrm{mol} / \mathrm{L}(6 \mathrm{mg} / \mathrm{dL})$ in women and 416 $\mu \mathrm{mol} / \mathrm{L}(7.0 \mathrm{mg} / \mathrm{dL})$ in men (Wallace et al., 1977).

Hyperuricemia is often diagnosed in patients with cardiovascular disease: however, there is controversy over considering uric acid as a risk factor, as the mechanism responsible for increased uric acid level in cardiovascular disease is not fully understood. Some studies suggest that high uric acid levels may be related to other risk factors like hypertension, dyslipidemia, obesity and diet, which contribute to an increase in cardiovascular risk. It has been shown that people with high uric acid levels may develop hypertension (De Becker et al., 2019). In addition, a high uric acid level contributes to lipid profile parameters such as TG and high-density lipoprotein cholesterol concentration (HDL-C) (Tian et al., 2015). On the other hand, there are factors that contribute to an increase in SUA concentration and correlate positively with an increased risk of cardiovascular disease. These include dietary factors like purine-rich products, fructose and alcohol.

An increased SUA concentration is also observed in postmenopausal women, especially those with cardiovascular disease and it is probably related to ovarian hormone deficiency. Some studies have shown that the SUA concentration in premenopausal women is about $20 \mu \mathrm{mol} / \mathrm{L}$ lower than in postmenopausal women (Wingrove et al., 1998). Additionally, it is worth noting that according to the latest Experts group recommendations, the uric acid level in women with a high cardiovascular risk should be $<5 \mathrm{mg} / \mathrm{dL}(<298 \mu \mathrm{mol} / \mathrm{L})$ (Borghi et al., 2018). This suggests that a SUA concentration $\geq 5 \mathrm{mg} / \mathrm{dL}$ may increase the cardiovascular risk in postmenopausal women.

The aim of this study was to analyse the relationship between the SUA concentration and cardiovascular risk factors such as lipid profile parameters, blood pressure, dietary factors and nutritional status in normotensive postmenopausal women with dyslipidemia. We have also estimated the correlation between PRAL value and SUA.

\section{MATERIAL AND METHODS}

The study included a group of 56 postmenopausal women characterized by normal blood pressure with dyslipidemia. The inclusion criteria in the study were serum total cholesterol (TC) concentration above 190 $\mathrm{mg} / \mathrm{dL}(\sim 5.0 \mathrm{mmol} / \mathrm{L})$, natural menopause (absence of menstrual period for at least 12 months), normal blood pressure (systolic blood pressure $<140 \mathrm{~mm} \mathrm{Hg}$ and diastolic blood pressure $<90 \mathrm{~mm} \mathrm{Hg}$ ) and not undergoing any medical treatment. Exclusion criteria were impaired glucose tolerance or diabetes; kidney, liver, thyroid or coronary heart disease; cancer, and cigarette smoking.

Women participating in the study were characterized by low physical activity, which was estimated by an activity questionnaire.

Participants in the study were classified into two groups according to their uric acid levels. The first group, the study group, consisted of women with a SUA concentration $\geq 5 \mathrm{mg} / \mathrm{dL}(\geq 298 \mu \mathrm{mol} / \mathrm{L})$ but without a diagnosis of gout. The second group, the control group, comprised women whose SUA concentration $<5 \mathrm{mg} / \mathrm{dL}(<298 \mu \mathrm{mol} / \mathrm{L})$. These values were based on recommendations, in women with increased cardiovascular risk, the target SUA concentration should be $<5 \mathrm{mg} / \mathrm{dL}$ (Borghi et al., 2018).

Women participating in this study were informed about the purpose of the research, anonymity and option of voluntary participation. Patients expressing a willingness to participate in the study and fulfilling the criteria signed the necessary statements, including consent to blood samples. The meetings with the women were carried out face-to-face. The study was approved by the Bioethics Committee at the Poznan University of Medical Sciences - Resolution No. 561/13.

Anthropometric measurements including body weight, height and waist, and hip circumferences were made. Measurements were taken according to current recommendations (Ness-Abramof and Apovian, 2008; WHO, 2000). The body-fat mass was assessed by the bioimpedance method using a Tanita Body Fat Analyzer (model - BC 420 S MA with a medical certificate).

The assessment of nutrition was evaluated through the method of 24-hour dietary recall over 4 days (including one day off work), according to the guidelines elaborated by the National Institute of Food and Nutrition (Charzewska, 1998). Each participant was trained to complete the dietary questionnaire properly. The amount of food consumed was estimated based on the photo album of products and dishes published 
Dobrzyńska, M., Przysławski, J. (2020). The relationship between serum uric acid concentration and cardiovascular risk factors in normotensive postmenopausal women with dyslipidemia. Acta Sci. Pol. Technol. Aliment., 19(1), 123-131. http://dx.doi. org/10.17306/J.AFS.2020.0740

by the Institute of Food and Nutrition (Szponar et al., 2000). The results obtained made it possible to calculate the energy and nutritional values of the all-day food rations. Relational databases developed in $\mathrm{Mi}-$ crosoft Access 2010 were used to analyze the composition of the diet (Kunachowicz et al., 2005). The calculations include the loss of vitamins during culinary and technological processes, amounting to vitamin C $-55 \%$ and vitamin E - 20\% (Nadolna, 1995). The energy and nutrient intake recommendations of the Institute of Food and Nutrition were taken into consideration while determining the degree to which the recommended energy and nutrients intakes were met (Jarosz, 2017). The cholesterol, fiber and saturated fatty acid (SFA) intake were compared with nutritional recommendations for cardiovascular disease prevention (Catapano et al., 2016).

Additionally, the structure of consumption in the two groups of women was estimated considering 10 groups of products (grain products, milk and dairy products, meat and fish products, eggs, butter, vegetable fats, vegetable and fruits and products of these, potatoes, legumes, sugar and sweets).

This study calculated the value of PRAL, an established variable for estimating the dietary acid load from dietary intake. An earlier population-based, cross-sectional study showed that PRAL value could be an independent predictor of SUA concentration. Some dietary factors, including PRAL, may be related to uric acid excretion. Thus, dietary alkalization may elevate SUA concentration. Potential renal acid load PRAL value was calculated according to the following formula (Esche et al., 2018):

PRAL, $\mathrm{mEq} / \mathrm{d}=0.49$ protein, $\mathrm{g} / \mathrm{d}+0.037$ phosphorus, $\mathrm{mg} / \mathrm{d}-0.021$ potassium, $\mathrm{mg} / \mathrm{d}-0.026$ magnesium, $\mathrm{mg} / \mathrm{d}-0.013$ calcium, $\mathrm{mg} / \mathrm{d}$

Biochemical tests were performed in the Central Laboratory of Gynecology and Obstetrics of the Clinical Hospital of Poznan University of Medical Sciences and they included the determination of uric acid concentration and lipid profile parameters (total cholesterol concentration and its fraction, triglyceride concentration) in serum.

Blood pressure was measured once, using a mercury column sphygmomanometer after the subject had been at rest in a seated position for $\geq 15$ minutes.

\section{Statistical methods}

The data were analyzed using the statistical program STATISTICA (version 13.1. StatSoft, Inc. 2017). The normality of the distribution was assessed using the Shapiro-Wilk test for normal distribution and equal variances and the Student's t-test for two independent groups. In the absence of normality, the Mann-Whitney U test was used. To estimate the possible influence of SUA concentration on the PRAL value, we used the Spearman rank correlation in this study. Statistical significance was set at a $P$ value of less than 0.05 .

\section{RESULTS}

The characteristics of the study subjects are presented in Table 1. Serum uric acid - SUA concentration was $5.9 \mathrm{mg} / \mathrm{dL}(351 \mu \mathrm{mol} / \mathrm{L})$ in the study group and 4.1 $\mathrm{mg} / \mathrm{dL}(244 \mu \mathrm{mol} / \mathrm{L})$ in the control group. For the anthropometric parameters, statistically significant differences were found between the groups only in the waist and hip circumferences and the WHR values.

Statistically significant differences in TG concentration were also observed. In other lipid profile parameters, no statistically significant differences were observed. Despite the normal values of systolic and diastolic blood pressures in all participants (according to the study criteria) a statistically significant difference was found between the groups in diastolic blood pressure.

The characteristics of the selected nutrients and energy are presented in Table 2.

The daily energy intake in the subjects in both the groups was slightly higher. The percentage of energy from protein and carbohydrates was consistent with the recommended values but those from fat were higher (norm: less than 35\%).

The statistically significant differences were observed between the groups in vitamin E, cholesterol, polyunsaturated fatty acid (PUFA), SFA and starch values. In other nutrients, no statistically significant differences were observed. An analysis of the structure of consumption showed differences between the groups in the consumption of some product groups such as grain products, milk and dairy products, meat and fish, butter, vegetables and fruits, and potatoes. The consumption of grain products, meat/fish and their products, butter and potatoes was significantly higher in the study group, while the consumption of milk and 
Dobrzyńska, M., Przysławski, J. (2020). The relationship between serum uric acid concentration and cardiovascular risk factors in normotensive postmenopausal women with dyslipidemia. Acta Sci. Pol. Technol. Aliment., 19(1), 123-131. http://dx.doi. org/10.17306/J.AFS.2020.0740

Table 1. The characteristics of the study subjects

\begin{tabular}{|c|c|c|c|}
\hline Parameter & $\begin{array}{l}\text { Study group } \\
\quad(n=22)\end{array}$ & $\begin{array}{l}\text { Control } \\
\text { group } \\
(n=34)\end{array}$ & $P$ value \\
\hline Age, yr & $54.5 \pm 5.5$ & $56.4 \pm 4.3$ & $0.1439^{*}$ \\
\hline Weight, kg & $75.9 \pm 20.7$ & $65.6 \pm 9.9$ & $0.0602^{* *}$ \\
\hline Height, cm & $162.1 \pm 5.4$ & $162.1 \pm 4.8$ & $0.9985^{*}$ \\
\hline BMI, $\mathrm{kg} / \mathrm{m}^{2}$ & $28.8 \pm 7.6$ & $25.0 \pm 3.7$ & $0.0547^{* *}$ \\
\hline $\begin{array}{l}\text { Waist circum- } \\
\text { ference, } \mathrm{cm}\end{array}$ & $95.7 \pm 15.8$ & $84.9 \pm 8.5$ & $0.0021^{* *}$ \\
\hline $\begin{array}{l}\text { Hip circum- } \\
\text { ference, } \mathrm{cm}\end{array}$ & $105.0 \pm 13.6$ & $101.1 \pm 11.9$ & $0.0133^{* *}$ \\
\hline WHR & $0.91 \pm 0.05$ & $0.86 \pm 0.05$ & $0.0005^{*}$ \\
\hline Body fat mass, \% & $37.5 \pm 7.1$ & $34.0 \pm 6.1$ & $0.0602^{*}$ \\
\hline Muscle mass, $\mathrm{kg}$ & $43.8 \pm 6.4$ & $40.6 \pm 3.2$ & $0.1187^{* *}$ \\
\hline $\begin{array}{l}\text { Systolic blood } \\
\text { pressure, } \mathrm{mm} \mathrm{Hg}\end{array}$ & $126.7 \pm 9.4$ & $123.6 \pm 10.0$ & $0.3600^{* *}$ \\
\hline $\begin{array}{l}\text { Diastolic blood } \\
\text { pressure, } \mathrm{mm} \mathrm{Hg}\end{array}$ & $79.9 \pm 6.2$ & $75.4 \pm 8.4$ & $0.0362^{*}$ \\
\hline $\mathrm{TC}, \mathrm{mg} / \mathrm{dL}$ & $236.2 \pm 32.7$ & $240.6 \pm 32.7$ & $0.6688^{* *}$ \\
\hline LDL-C, mg/dL & $144.1 \pm 33.8$ & $145.3 \pm 34.4$ & $0.9006^{*}$ \\
\hline HDL-C, mg/dL & $66.6 \pm 14.4$ & $75.1 \pm 18.4$ & $0.0825^{* *}$ \\
\hline $\mathrm{TG}, \mathrm{mg} / \mathrm{dL}$ & $127.0 \pm 66.5$ & $97.3 \pm 40.2$ & $0.0298^{* *}$ \\
\hline SUA, mg/dL & $5.9 \pm 1.0$ & $4.1 \pm 0.5$ & $0.0000^{*}$ \\
\hline
\end{tabular}

Study group - women with a SUA concentration $\geq 5 \mathrm{mg} / \mathrm{dL}$. Control group - women with a SUA concentration $<5 \mathrm{mg} / \mathrm{dL}$. BMI - body mass index, HDL-C - high-density lipoprotein cholesterol concentration, LDL-C - low-density lipoprotein cholesterol concentration, SUA - serum uric acid, TC - total cholesterol, TG - triglycerides, WHR - waist to hip ratio.

"Student's t-test for two independent groups.

${ }^{* *}$ Mann-Whitney U test.

$P$ values $<0.05$ are considered significant.

dairy products, vegetable and fruits was higher in the control group. There were no differences in the consumption of eggs, vegetable fats, legumes, sugar, and sweets (Fig. 1).
Table 2. The characteristics of the energy and selected nutrients in the groups

\begin{tabular}{|c|c|c|c|}
\hline Parameter & $\begin{array}{l}\text { Study } \\
\text { group } \\
(n=22)\end{array}$ & $\begin{array}{l}\text { Control } \\
\text { group } \\
(n=34)\end{array}$ & $P$ value \\
\hline Energy, kcal/d & $2257 \pm 445$ & $2124 \pm 375$ & $0.2333^{*}$ \\
\hline Protein, E\% & $15.2 \pm 2.1$ & $15.5 \pm 2.6$ & $0.7285^{*}$ \\
\hline Carbohydrates, E\% & $48.0 \pm 4.7$ & $49.8 \pm 7.1$ & $0.3142^{*}$ \\
\hline Saccharose, E\% & $8.4 \pm 2.8$ & $9.7 \pm 3.3$ & $0.1558^{*}$ \\
\hline Starch, g/d & $155 \pm 34$ & $128 \pm 39$ & $0.0087^{*}$ \\
\hline Fructose, $\mathrm{g} / \mathrm{d}$ & $1.5 \pm 1.1$ & $2.3 \pm 2.3$ & $0.2505^{* *}$ \\
\hline Dietary fibre, $g / d$ & $22.6 \pm 5.4$ & $24.9 \pm 9.1$ & $0.2926^{*}$ \\
\hline Fat, E\% & $40.0 \pm 4.4$ & $38.6 \pm 5.9$ & $0.3486^{*}$ \\
\hline SFA, E\% & $14.2 \pm 4.0$ & $11.5 \pm 2.9$ & $0.0059^{*}$ \\
\hline MUFA, E\% & $15.7 \pm 2.4$ & $15.3 \pm 2.8$ & $0.6236^{*}$ \\
\hline PUFA, E\% & $6.6 \pm 1.7$ & $8.4 \pm 3.1$ & $0.0146^{* *}$ \\
\hline Cholesterol, mg/d & $567 \pm 245$ & $399 \pm 185$ & $0.0052^{*}$ \\
\hline Vitamin $\mathrm{D}, \mu \mathrm{g} / \mathrm{d}$ & $1.2 \pm 1.4$ & $0.8 \pm 0.8$ & $0.2646^{* *}$ \\
\hline Vitamin E, mg/d & $11.1 \pm 2.7$ & $13.0 \pm 3.3$ & $0.0235^{*}$ \\
\hline Vitamin $\mathrm{C}, \mathrm{mg} / \mathrm{d}$ & $47.6 \pm 23.1$ & $59.5 \pm 33.4$ & $0.1613^{* *}$ \\
\hline Sodium, mg/d & $2361 \pm 735$ & $2269 \pm 652$ & $0.5403^{* *}$ \\
\hline Potassium, mg/d & $3451 \pm 707$ & $3598 \pm 780$ & $0.4776^{*}$ \\
\hline Magnesium, mg/d & $352 \pm 105$ & $375 \pm 112$ & $0.4348^{*}$ \\
\hline Phosphorus, mg/d & $1450 \pm 335$ & $1414 \pm 379$ & $0.7179^{*}$ \\
\hline PRAL, mEq/d & $5.7 \pm 11.6$ & $-2.0 \pm 12.2$ & $0.0258^{*}$ \\
\hline
\end{tabular}

Study group - women with a SUA concentration $\geq 5 \mathrm{mg} / \mathrm{dL}$. Control group - women with a SUA concentration $<5 \mathrm{mg} / \mathrm{dL}$. MUFA - monounsaturated fatty acids, PRAL - potential renal acid load, PUFA - polyunsaturated fatty acids, SFA - saturated fatty acids, SUA - serum uric acid.

*Student's t-test for two independent groups.

${ }^{* *}$ Mann-Whitney U test.

$P$ values $<0.05$ are considered significant.

Furthermore, a correlation was observed between SUA concentration and the PRAL value $(\mathrm{PRAL}=$ $-19.4316+4.2695$ SUA) (Fig. 2). 
Dobrzyńska, M., Przysławski, J. (2020). The relationship between serum uric acid concentration and cardiovascular risk factors in normotensive postmenopausal women with dyslipidemia. Acta Sci. Pol. Technol. Aliment., 19(1), 123-131. http://dx.doi. org/10.17306/J.AFS.2020.0740

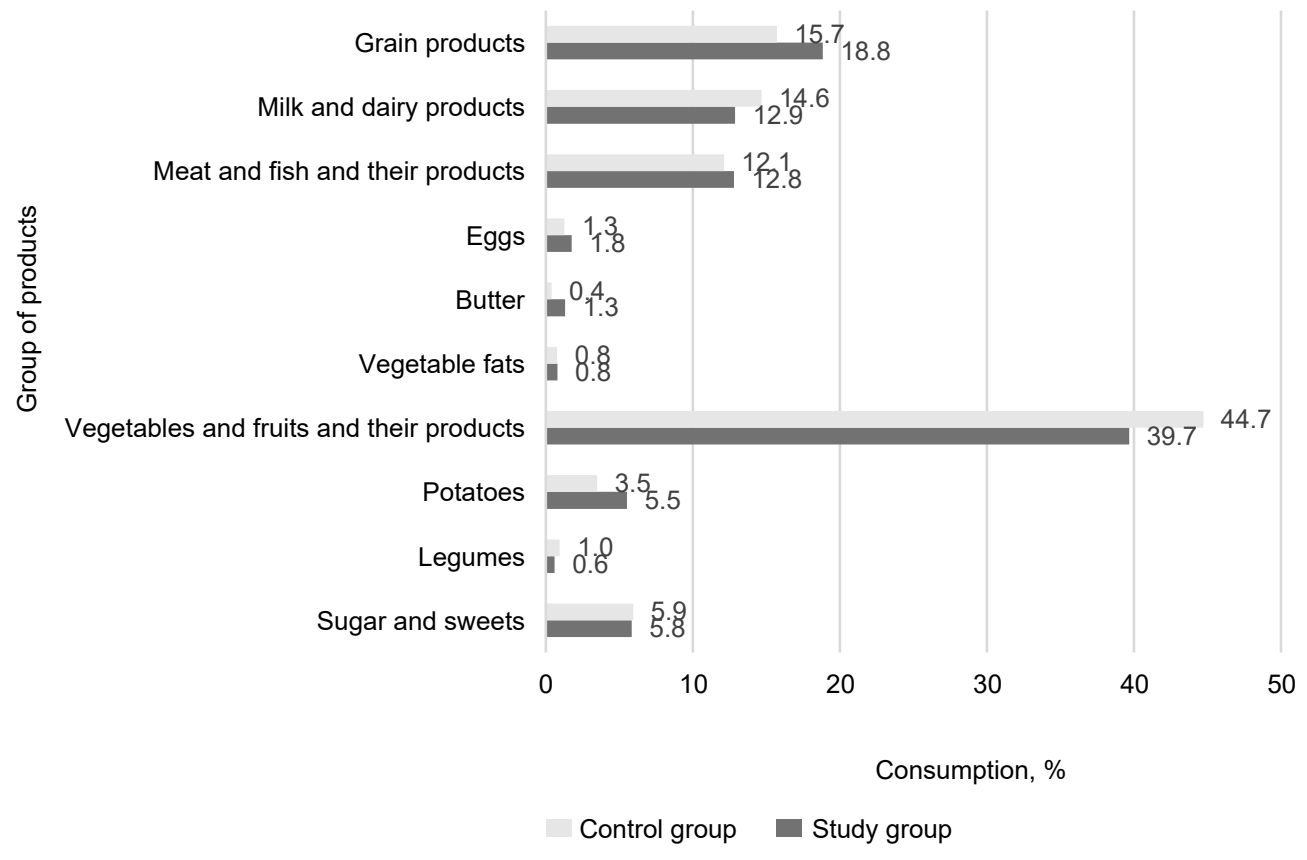

Fig. 1. The structure of consumption in the groups of women

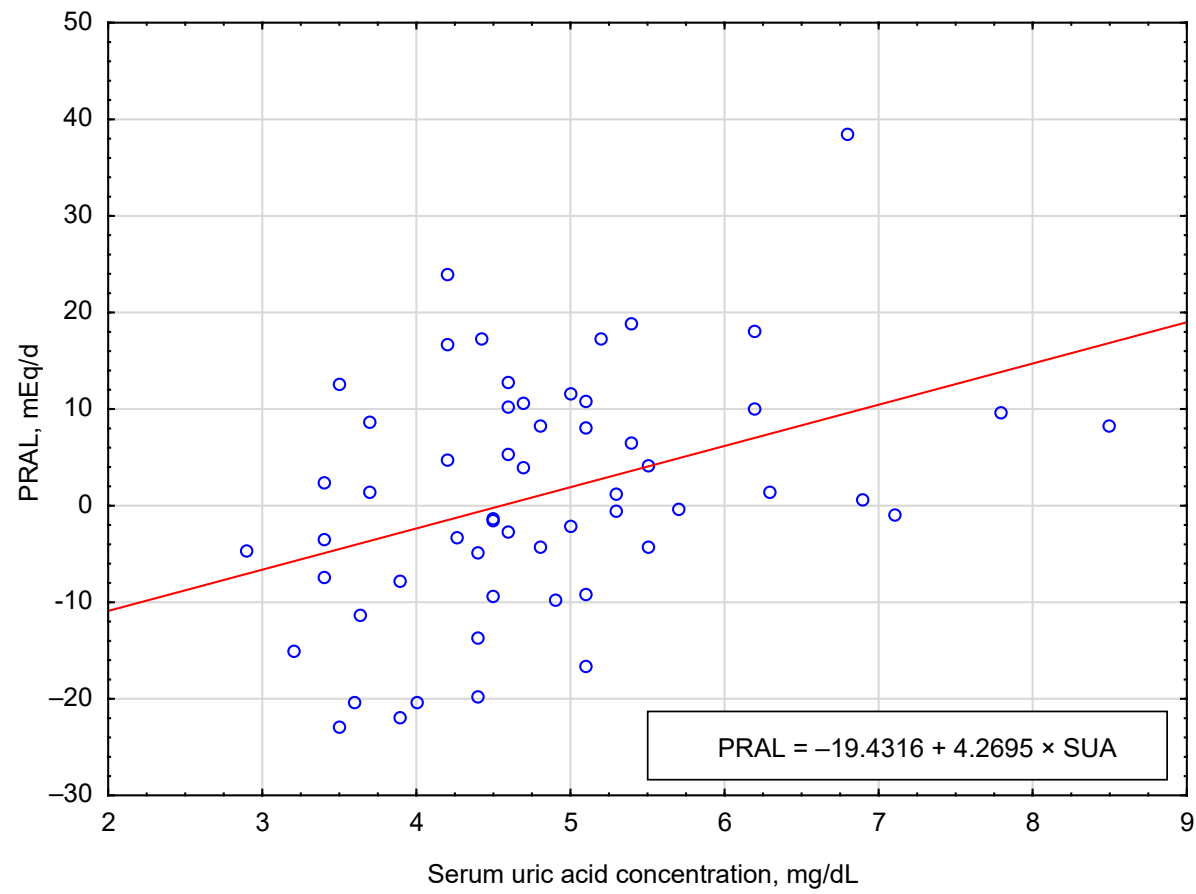

Fig. 2. The correlation between SUA and PRAL in all the women studied 


\section{DISCUSSION}

Many studies have shown a relationship between hyperuricemia and cardiovascular disease (Kostka-Jeziorny et al., 2019; Kowalski et al., 2009; Zhang et al., 2019). Several studies on hyperuricemia patients have reported SUA concentration as a marker of pathophysiology processes that correlated with the development of cardiovascular disease (Zhang et al., 2019). Only a few studies have investigated the correlation between SUA concentration and cardiovascular disease in patients without hyperuricaemia. Currently, it is believed that the risk of cardiovascular disease increases from $5.0 \mathrm{mg} / \mathrm{dL}$, before the diagnosis of hyperuricemia (Kostka-Jeziorny et al., 2019).

Our study showed that the SUA concentration $\geq 5.0 \mathrm{mg} / \mathrm{dL}$ was related with a few cardiovascular risk factors in the group of normotensive postmenopausal women with dyslipidemia. This applies to selected anthropometric parameters, such as serum TG concentrations and some dietary factors.

As currently understood, the relationship between SUA concentration and anthropometric parameters like BMI, WHR and body fat content is probably explained by the influence of diet. In our study, a positive correlation was observed in WHR values. A strong positive correlation between SUA and WHR was also observed in the study by Lee et al. (1995). The mechanism of this effect has not yet been fully elucidated. It is probably related to visceral fat content. Some studies have shown that higher waist circumference and SUA concentration are independently related to leptin concentration (Bedir et al., 2003). No correlation was observed between the BMI value and SUA concentration in our study ( $p=0.0547)$. Interestingly, in the study by Zhou et al. (2017) the relationship between BMI and SUA was observed only in patients with $\mathrm{SUA} \geq 6 \mathrm{mg} / \mathrm{dL}$.

Regarding lipid profile parameters, we observed a statistically significant difference between the groups only in TG concentration. As per the latest literature, the association between lipid profile parameters and SUA level varies with participants and sample sizes (Tian et al., 2015). Generally, SUA concentration positively related to TG, TC, and low-density lipoprotein cholesterol concentration (LDL-C) and negatively related to HDL-C. The mechanism that links these parameters is not yet fully understood and needs further study. Some studies assume that the synthesis of TG requires nicotinamide adenine dinucleotide phosphate, which results in increased SUA production (Greiling et al., 1977). Co-occurrence of increased TG concentration and SUA level may be associated with strong interactions between them or with another factor that simultaneously affects these two parameters. Nevertheless, the observed association between SUA level and TG suggests that their concentrations should be monitored together.

An interesting observation in the study concerned blood pressure. Despite the exclusion of women with hypertension from the study, we observed a statistically significant difference between the groups in diastolic blood pressure. According to the current literature, SUA has a positive association with both systolic and diastolic blood pressures. However, some studies have shown the correlation of SUA with only diastolic blood pressure (Kostka-Jeziorny et al., 2019). Some epidemiological studies have shown that SUA concentration strongly correlates with diastolic blood pressure, even in patients without hypertension (Yano et al., 1977).

This may indicate that the effect of SUA on diastolic blood pressure is observed even from a concentration lower than $5 \mathrm{mg} / \mathrm{dL}$.

Many multiple observational studies have shown a strong association between hyperuricemia and hypertension, both for systolic and diastolic blood pressures (De Becker et al., 2019). This is related to higher uric acid levels increasing the activation of the reninangiotensin-aldosterone system, resulting in elevated blood pressure.

The relation between diet and SUA concentration has not yet been fully understood (Krupp et al., 2017). In recent years, attention has been paid to some dietary factors which may affect thte SUA concentration. Factors that may increase the SUA concentration include purine-rich products, a low-sodium diet, increased consumption of red meat, fructose and alcohol, and added sugar. However, increased consumption of dairy products, legumes and products rich in vitamin C may reduce the SUA concentration (Beydoun et al., 2018).

The diet of postmenopausal women with dyslipidemia should be balanced due to the increased risk of cardiovascular disease. Fat intake, especially of 
Dobrzyńska, M., Przysławski, J. (2020). The relationship between serum uric acid concentration and cardiovascular risk factors in normotensive postmenopausal women with dyslipidemia. Acta Sci. Pol. Technol. Aliment., 19(1), 123-131. http://dx.doi. org/10.17306/J.AFS.2020.0740

saturated fatty acids, should be limited. Intake of dietary fibre, unsaturated fatty acids, and antioxidant vitamins should be increased (Piepoli et al., 2016).

Analysis of all-day food rations showed that the women in both groups consumed too much fat, SFA and cholesterol. Interestingly, the total energy value in both groups only slightly exceeded the guidelines of the Institute of Food and Nutrition (Jarosz, 2017). Additionally, the diet contained inadequate amounts of dietary fibre, vitamin D and vitamin C. Statistically significant differences were observed between the groups in terms of starch, SFA, PUFA, cholesterol and vitamin $\mathrm{E}$ content. This suggests that the nutrient intake may have contributed to the SUA concentration.

Increased intake of SFA and cholesterol and reduced intake of PUFA in the group of women studied was associated with the increased consumption of meat products and butter. Therefore, the concentration of SUA in this group of women was associated either with an increased intake of purine-rich products (offal) or with the intake of the abovementioned fatty acids. So far, no mechanisms that connect the SUA level with the fatty acid profile of the diet have been found. However, some studies have shown that dietary intervention associated with a modification of the intake of fatty acids affects the SUA concentration (Galvão Cândido et al., 2018).

Increased intake of starch in the group of women who were studied was associated with increased consumption of potatoes. No relationship between increased intake of starch and SUA concentration has been observed yet in the available literature. The percentage from starch in the study group was higher than $5 \%$. In addition, it is worth noting that in this study, starch was derived from cooked potatoes, which are characterized by a high glycemic index. Moreover, there were no statistically significant differences in fructose intake between the groups, but the energy from fructose did not exceed $2.5 \%$. Some studies have shown that a high fructose intake contributes to obesity, hypertension, higher TG, and increased SUA concentration (Ha et al., 2013). According to the Canadian Diabetes Association guidelines, the daily intake of fructose should not exceed $10 \%$ of the total energy intake. These guidelines also indicate that the increase in SUA concentration is observed if the daily fructose intake is higher than $60 \mathrm{~g}$ (Dworatzek et al., 2013).
In our study, we observed a positive linear association between dietary acid load and SUA concentration. Similar results were observed in a study of a German population (Esche et al., 2018). The mechanism linking PRAL with SUA concentration is poorly understood. Some studies have shown that an alkalizing diet (rich in fruits and vegetables) increases renal uric acid excretion and decreases SUA concentrations (Kanbara et al., 2012). An analysis of the consumption pattern in our study confirmed that the study group was eating fewer fruits and vegetables, and products of these, compared to the control group. Thus, a diet rich in vegetables and fruits may help reduce the SUA level. Furthermore, a low PRAL value may represent a potentially SUA-reducing dietary pattern.

The limitations of the present study include a relatively small number of participants. Larger randomized, clinical trials will provide more definitive results. We used self-report techniques to estimate the physical activity level. In further research, it is worth using the International Physical Activity Questionnaire (IPAQ). In addition, blood pressure measurements should be performed according to the current recommendations of the American Heart Association.

The research requires determining the relationship between SUA concentration and dietary factors in particular, determining which of the dietary factors play a role in cardiovascular risk, the food product or the nutrient component in this product.

\section{CONCLUSION}

In conclusion, the relationship between SUA and cardiovascular risk factors depends on the concentration of SUA. A SUA concentration $>5 \mathrm{mg} / \mathrm{dL}$ may positively related to some cardiovascular risk. Additionally, PRAL, as a dietary factor, may help estimate the correctness of the diet plan in patients with an increased SUA concentration. The results obtained indicate the need for further research on large groups.

\section{REFERENCES}

Batta, A. (2016). Uric acid is a significant antioxidant. EJPMR, 3(8), 242-248.

Bedir, A., Topbas, M., Tanyeri, F., Alvur, M., Arik, N. (2003). Leptin might be a regulator of serum uric acid concentra- 
Dobrzyńska, M., Przysławski, J. (2020). The relationship between serum uric acid concentration and cardiovascular risk factors in normotensive postmenopausal women with dyslipidemia. Acta Sci. Pol. Technol. Aliment., 19(1), 123-131. http://dx.doi. org/10.17306/J.AFS.2020.0740

tions in humans. Jpn Heart. J., 44(4), 527-536. https://doi. org/10.1536/jhj.44.527

Beydoun, M. A., Fanelli-Kuczmarski, M. T., Canas, J. A., Beydoun, H. A., Evans, M. K., Zonderman, A. B. (2018). Dietary factors are associated with serum uric acid trajectory differentially by race among urban adults. Br. J. Nutr., 120(8), 935-945. https://doi.org/10.1017/ S0007114518002118

Borghi, C., Tykarski, A., Widecka, K., Filipiak, K. J., Domienik-Karłowicz, J., Kostka-Jeziorny, K., ..., Mancia, G. (2018). Expert consensus for the diagnosis and treatment of patient with hyperuricemia and high cardiovascular risk. Cardiol. J., 25(5), 545-563. https://doi. org/10.5603/CJ.2018.0116

Catapano, A. L., Graham, I., De Backer, G., Wiklund, O., Chapman, M. J., Drexel, H., ..., Zamorano, J. L. (2016). 2016 ESC/EAS Guidelines for the management of dyslipidaemias: The task force for the management of dyslipidaemias of the European Society of Cardiology (ESC) and European Atherosclerosis Society (EAS) developed with the special contribution of the European Assocciation for Cardiovascular Prevention \& Rehabilitation (EACPR). Atherosclerosis, 253, 281-344 https:// doi.org/10.1016/j.atherosclerosis.2016.08.018

Charzewska, J. (1998). Instrukcja przeprowadzania wywiadu o spożyciu z 24 godzin [Instruction of the dietary recall gathering from the last 24 hours]. Warszawa: Instytut Żywności i Żywienia [in Polish].

De Becker, B., Borghi, C., Burnier, M., van de Borne, P. (2019). Uric acid and hypertension: a focused review and practical recommendations. J. Hypertens., 37(5), 878883. https://doi.org/10.1097/HJH.0000000000001980

Dworatzek, P. D., Arcudi, K., Gougeon, R., Husein, N., Sievenpiper, J. L., Williams, S. L. (2013). Nutrition therapy. Can. J. Diabet., 37(1) S45-S55. https://doi. org/10.1016/j.jcjd.2013.01.019

Esche, J., Krupp, D., Mensink, G. B. M., Remer, T. (2018). Dietary potential renal acid load is positively associated with serum uric acid and odds of hyperuricemia in the German adult population. J. Nutr., 148(1), 49-55. https://doi.org/10.1093/jn/nxx003

Galvão Cândido, F., Xavier Valente, F., da Silva, L. E., Gonçalves Leão Coelho, O., Gouveia Peluzio, M. D. C., Gonçalves Alfenas, R. C. (2018). Consumption of extra virgin olive oil improves body composition and blood pressure in women with excess body fat: a randomized, double-blinded, placebo-controlled clinical trial. Eur. J. Nutr., 57(7), 2445-2455. https://doi.org/10.1007/ s00394-017-1517-9
Greiling, H., van Wersch, J., Karatay, C. (1977). The NADP/ $\mathrm{NADPH}_{2}$ ratio in erythrocytes of hyperuricemic patients, a possible regulator between purine, carbohydrate and lipid metabolism. Adv. Exp. Med. Biol., 76A, 553-556. https://doi.org/10.1007/978-1-4613-4223-6_69

Ha, V., Jayalath, V. H., Cozma, A. I., Mirrahimi, A., de Souza, R. J., Sievenpiper, J. L. (2013). Fructose-containing sugars, blood pressure, and cardiometabolic risk: a critical review. Curr. Hypertens. Rep., 15(4), 281-297. https://doi.org/10.1007/s11906-013-0364-1

Jarosz, M. (2017). Nutrition standards for the population of the Polish. Warsaw: National Food and Nutrition Institute.

Kanbara, A., Miura, Y., Hyogo, H., Chayama, K., Seyama, I. (2012). Effect of urine $\mathrm{pH}$ changed by dietary intervention on uric acid clearance mechanism of $\mathrm{pH}$-dependent excretion of urinary uric acid. Nutr. J., 11, 39. https:// doi.org/10.1186/1475-2891-11-39

Kostka-Jeziorny, K., Widecka, K., Tykarski, A. (2019). Study of epidemiological aspects of hyperuricemia in Poland. Cardiol. J., 26(3), 241-252. https://doi.org/10.5603/CJ.a 2019.0034

Kowalski, J., Krzemińska, A., Banach, M., Pawlicki, L., Śliwczyńska-Rodziewicz, D., Barylski, M. (2009). The concentration of uric acid in patients with metabolic syndrome and cardiovascular diseases. Cent. Eur. J. Med., 4(3), 272-278. https://doi.org/10.2478/s11536009-0026-5

Krupp, D., Esche, J., Mensink, G. B., Neuhauser, H. K., Remer, T. (2017). Diet-independent relevance of serum uric acid for blood pressure in a representative population sample. J. Clin. Hypertens. (Greenwich), 19(10), 1042-1050. https://doi.org/10.1111/jch.13046

Kunachowicz, H., Nadolna, I., Przygoda, B., Iwanow, K. (2005). Tabele składu i wartości odżywczej żywności [Tables of nutritious value of food products]. Warszawa: Państwowy Zakład Wydawnictw Lekarskich [in Polish]. Lee, J., Sparrow, D., Vokonas, P. S., Landsberg, L., Weiss, S. T. (1995). Uric acid and coronary heart disease risk: evidence for a role of uric acid in the obesity-insulin resistance syndrome. The normative aging study. Am. J. Epidemiol., 142(3), 288-294. https://doi.org/10.1093/ oxfordjournals.aje.a117634

Luo, Q., Xia, X., Li, B., Lin, Z., Yu, X., Huang, F. (2019). Serum uric acid and cardiovascular mortality in chronic kidney disease: a meta-analysis. BMC Nephrol., 20, 18. https://doi.org/10.1186/s12882-018-1143-7

Nadolna, I. (1995). Zachowanie witamin w procesach kulinarnych i technologicznych [Vitamins changes during culinary and technological processed]. Nowa Med., 11, 20-23 [in Polish]. 
Dobrzyńska, M., Przysławski, J. (2020). The relationship between serum uric acid concentration and cardiovascular risk factors in normotensive postmenopausal women with dyslipidemia. Acta Sci. Pol. Technol. Aliment., 19(1), 123-131. http://dx.doi. org/10.17306/J.AFS.2020.0740

Ness-Abramof, R., Apovian, C. M. (2008). Waist circumference measurement in clinical practice. Nutr. Clin. Pract., 23(4), 397-404. https://doi.org/10.1177/08845336083 21700

Piepoli, M. F., Hoes, A. W., Agewall, S., Albus, Ch., Brotons, C., Catapano, A. L., ..., Binno, S. (2016). 2016 European Guidelines on cardiovascular disease prevention in clinical practice: The Sixth Joint Task Force of the European Society of Cardiology and Other Societies on Cardiovascular Disease Prevention in Clinical Practice (constituted by representatives of 10 societies and by invited experts) developed with the special contribution of the European Association for Cardiovascular Prevention \& Rehabilitation (EACPR). Eur. Heart. J., 37(29), 2315-2381. https://doi.org/10.1093/eurheartj/ehw106

Szponar, L., Wolnicka, K., Rychlik, E. (2000). Album fotografii produktów i potraw [Album of photographs of food products and dishes]. Warszawa: Instytut Żywności i Żywienia [in Polish].

Tian, Y., Chen, K., Xie, Z., Fang, Y., Wang, H., Nie, Y., ..., $\mathrm{Mu}$, Y. (2015). The association between serum uric acid levels, metabolic syndrome and cardiovascular disease in middle aged and elderly Chinese: results from the DYSlipidemia International Study. BMC Cardiovasc. Disord., 15, 66. https://doi.org/10.1186/s12872-0150059-4
Wallace, S. L., Robinson, H., Masi, A. T., Decker, J. L., McCarty, D. J., Yü, T. F. (1977). Preliminary criteria for the classification of the acute arthritis of primary gout. Arthritis. Rheum., 20(3), 895-900. https://doi.org/10.1002/ art. 1780200320

Wingrove, C. S., Walton, C., Stevenson, J. C. (1998). The effect of menopause on serum uric acid levels in nonobese healthy women. Metabolism, 47(4), 435-438. https://doi.org/10.1016/S0026-0495(98)90056-7

WHO (2000). Report of WHO consultation. Obesity: preventing and managing the global epidemic. Report of a WHO consultation. World Health Organization. Tech. Rep. Ser., 894(i-xii), 1-253.

Yano, K., Rhoads, G., Kagan, A. (1977). Epidemiology of serum uric acid among 8000 Japanese-American men in Hawaii. J. Chronic. Dis., 30(3), 171-184. https://doi. org/10.1016/0021-9681(77)90083-2

Zhang, S., Wang, Y., Cheng, J., Huangfu, N., Zhao, R., Xu, Z., ..., Zhang, D. (2019). Hyperuricemia and cardiovascular disease. Curr. Pharm. Des., 25(6), 700-709. https://doi.org/10.2174/1381612825666190408122557

Zhou, H., Wang, Y., Cui, L., Chen, Y., Li, C., Zhao, J. (2017). The ongoing role of serum uric acid in blood pressure. Clin. Exp. Hypertens., 39, 601-605. https://doi.org/10.1 080/10641963.2017.1299750 